\title{
RELIGION AND SCIENCE: FINDING THE RIGHT QUESTIONS
}

\author{
by Taede A. Smedes
}

As one of the younger scholars in religion and science, I have a slightly different perspective on the field, a view not all other scholars in the field may appreciate. $M$ y perspective is strongly influenced by European-especially Kantian, hermeneutic, and Wittgensteinian-philosophy. As a consequence I strongly emphasize the difference between science and religion and am suspicious of attempts to integrate both. Although I am in favor of a dialogue between science and religion, I often focus on fundamental issues that I believe are nowadays too often neglected and that I think are crucial for the future of the field of science and religion.

Looking at that field today, I feel a growing unease with the way it is developing, especially in theEnglish-speaking countries. In my book Chaos, Complexity, and God (Smedes 2004) I pinpointed my uneasiness by critically examining the approaches of two highly influential exponents of the contemporary field: John Polkinghorne and the recently deceased Arthur Peacocke. I tried to show that Polkinghorne and Peacocke (but this also pertains to many other scholars in the field today) adhere to a cultural form of scientism that has become part of our cultural heritage as a product of the conceptual revolution that occurred during the European Enlightenment and that showed a huge esteem for especially physical (N ewtonian) science.

In everyday life, scientific thinking and a scientific perception of reality has gained prominence over religious ways of seeing and experiencing the world. We do not even notice our scientific bias anymore. Science is considered a priori rational, and theology has to live up to the standards of scientific rationality if it wants to betaken seriously. In such a perspective, I believe theology is not taken seriously as the hermeneutical enterprise that it is. It is seen as a kind of pseudoscience in which talk about $\mathrm{God}$ is on the same level as talk about the cat on the mat and the tree in the garden.

Taede A. Smedes is Junior Fellow at the Faculty of Theology of the Katholieke Universiteit Leuven. $H$ is mailing address is Lodewijk van D eyssellaan $51,2182 \mathrm{VN}, \mathrm{H}$ illegom, the N etherlands; e-mail tasmedes@tasmedes.nl. 
Thecultural scientism has gained a strong foothold in dealing with theological matters as well. Take divine action. Peacockeand Polkinghornetry to resolve the question that haunts many modern believers today: H ow can we meaningfully speak about divine action in a world that science seems so successful in explaining through natural causal mechanisms? In order to deal with this question, they search for a place for $\mathrm{G}$ od within the scientific framework. They look at chaos theory (Polkinghorne) and selforganization and emergence (esp. Peacocke) to argue for the openness of the world to God. But they could have taken other approaches, such as neuroscience or quantum mechanics; these al so have been taken as potentially fruitful for addressing the issue of divine action. However, all of these approaches remain completely vacuous if the fundamental question is left unanswered: W hy turn to science to address a theological or religious question?

The obvious answer is that science has become our sole heuristic instrument to tackle questions that relate to our world. Ever since the modern field of science and religion emerged in the early 1960s, with the publication of Ian Barbour's Issues in Science and Religion (1966) and with the emergence of the journal Zygon, the influence of science upon the field has grown while that of theology has diminished. N owadays it seems as if scientists are more involved in the field than theologians are. A look at some systematic theologies published in the last ten years reveals that science-and-religion is hardly mentioned and seems to have no impact on theology. The big exception is Wolfhart Pannenberg's three-volume Sys tematic Theol ogy (1991-1997), but, generally speaking, the field of science and religion is hardly perceived by theologians. T his is the case not only in the United States but also in Europe.

If theologians are not taking the dialogue seriously, who is? Scientists? W hy should scientists takenotice of discussions that pertain to an "Entity" (which is already the wrong word) that is irrelevant to scientific research because it is deemed transcendent? What place is there then for sciencereligion dialogue? Who is the audience? For whom do we give lectures, write books and articles?

I fear it is for our own in-group of colleagues. I am serious about this. As I see it, the field of science and religion has become a closed arena, where a relatively small group of scholars, professionally active in other fields of scientific or theological research, devote some of their time and money to satiffy a shared obsession with peculiar questions about the intersection of the transcendent and the immanent. The dialogue between science and religion has become a game with certain rules about which questions are allowed and which kinds of answers are accepted. It is a game with no other goal than to play the game as best as one can. There are no winners or losers, only some scholars who are better at playing the 
game because they are able to devote more time to it. In other words, the field of science and religion has become an end in itself.

$\mathrm{H}$ ow can the field regain momentum? Perhaps there is something to be learned from the past.

In the N etherlands about forty years ago, two books appeared, in 1965 and 1967, that together constitute the final report of the multidisciplinary Committee of Faith and the $\mathrm{N}$ atural Sciences. This Committee had been given an assignment by the Dutch Reformed Church, fourteen years earlier in 1951, to investigate the interaction of religion and science. The preface of the first volume allows a small glance behind the scenes of what went on during the fourteen years of discussions and meetings. The editors write that the conversations between scientists and theologians were almost cancelled prematurely because the participants were unable to decide on the theme or contents of future deliberations, due to a lack of problems (D ippel and De Jong 1965, xi). All of the participants rejected the view that religion and scienceare in conflict. Such a conflict is possible if the parties believe that science and religion are competitors on the same market, and this view the participants rejected. Being influenced by the German hermeneutical tradition, they accepted a functional and conceptual separation of science and religion. Both scientists and theologians, however, were at the same time convinced that a dialogue was possible. But how?

W hat seemed initially such a simple task- establishing a dialogue be tween theology and science- turned out to be incredibly difficult. The participants were aware that the dial ogue was no goal in itself. Because of the rapidly changing scientific worldview, and because of the ethical questions related to the threat of technological devastation in the heat of the Cold War, the members of the Committee remained true to their assignment. To establish a dialogue that transcended the differences, scientists and theologians taught each other about their respective fields, because all participants agreed on a basic understanding of hermeneutical principlesthat to establish a dialogue the parties need to understand each other's perspective. So, in the fourteen years that ensued, theologians explained to scientists the basic notions of Christian theology, while scientists explained to theologians the foundations of the scientific worldview. The participants of the dialogue did not shy away from facing philosophical difficulties and fundamental questions: What is theology? W hat is science? H ow do they differ from and relate to each other? The Committee did not resolve any problems, but at least they learned to rule out the wrong questions- a splendid start! And in the process, they were conducting the dialogue they were searching for- simply by doing it.

If the field of science and religion wants to remain theologically and culturally relevant, it needs to address those basic and fundamental questions that many today seem to have lost sight of. Barbour, in his earlier 
works (1966; 1974), acknowledged the fundamental differences between the scientific and religious outlook, yet at the same time he felt the need to bring them together. H e believed the basic issues to be (1) philosophical: W hat constitutes the differences between science and religion? (2) anthropol ogical: W hat is humanity's relation to nature both scientifically and theologically? and ultimately (3) theological: H ow can we conceive of God's relation to nature in an age of science?

Instead of jumping straightaway to the answers, we first should take our time to think of the right questions. Fortunately, the need to find the right questions is recognized by the younger generation of scholars in science and religion. There is hope.

\section{REFEREN CES}

Barbour, Ian G. 1966. I ssues in Science and Theology. Englewood Cliffs, N .J.: Prentice H all. - - - . 1974. M yths, M odels, and Paradigms: A Comparative Study in Science and Religion. San Francisco: $\mathrm{H}$ arper and Row.

Dippel, Cornelius J., and Johannes M. de Jong. 1965. Geloof en natuurwetenschap: Studies over de verhouding van christelijk gel oof en moderne natuurweten schap, D el I: Scheppingsgel oof, natuur, natuurwetenschap, 's-G ravenhage, the N etherlands: Boekencentrum.

Pannenberg, Wolfhart. 1991-1997. Systematic Theology. 3 vols. Edinburgh: T\& T Clark, and Grand Rapids, M ich.: Eerdmans.

Smedes, Taede A. 2004. Chaos, Complexity, and God: Divine Action and Scientism. Leuven, Belgium: Peeters. 